\title{
Dr. Sören Fex, MD, PhD
}

\section{Editor-in-Chief 1995-2001}

With the start of volume 5, 2002 Dr. Sören Fex stepped down as the Editor-in-Chief of the official journal of the International Association of Logopedics and Phoniatrics (IALP). According to a decision of the Board of the IALP, the office of Editor-in-Chief and Chairman of the Standing Committee of Scientific Journal Affairs is restricted to two terms of 3 years. In the past 6 years Dr. Fex served the IALP and Folia Phoniatrica et Logopaedica in ways that are typical of the person of Sören as we have come to know him. He established an excellent working system with both the publisher and the editors assigned to specific fields of interest.
Dr. Fex had long experience as a Member of the Editorial Board when he began his term as Editor-in-Chief. Almost 30 years ago he had already been mentioned on the Editorial Board page of Folia as Redactore. Names changed, Redactores became Editors, Folia Phoniatrica became Folia Phoniatrica et Logopaedica, but Sören Fex stayed, rightfully succeeding to the position of Folia's Editorin-Chief.

We are grateful to Sören for all his efforts for Folia, and we want to thank him most heartily.

Harm K. Schutte, President of the IALP Editor-in-Chief Folia Phoniatrica et Logopaedica

\begin{tabular}{ll}
\hline KARGER & ( ) 2002 S. Karger AG, Basel \\
1021-7762/02/0543-0116\$18.50/0 \\
$\begin{array}{l}\text { Fax +4161306 1234 } \\
\text { Ewail karger@karger.ch } \\
\text { wwarger.com }\end{array}$ & $\begin{array}{l}\text { Accessible online at: } \\
\text { www.karger.com/journals/fpl }\end{array}$
\end{tabular}

